\title{
The Arabs in the (Inter)national
}

\author{
Haider Ala Hamoudi*
}

* Assistant Professor of Law, University of Pittsburgh School of Law; Non-Resident Senior Fellow, Institute of Iraq Studies, Boston University. JD and JSD, Columbia University School of Law. I would like to thank Bert Westbrook, Lama Abu- Odeh, Asifa Quraishi and David Ball for their helpful comments and suggestions. Any errors are mine alone. 


\section{Introduction}

Professor Abu-Odeh is nothing if not provocative. I mean this in the most positive way possible, as one who challenges traditional orthodoxies, an iconoclast seeking to demystify areas of law where there has been all too much mystification. I for one consider myself indebted to her earlier provocations, awakening me, to adopt Kant's memorable phrasing, from my "dogmatic slumber[s]."1 On the attack against traditional notions of the reification of Islamic law as a construct of scholarly opinions of men long dead, Professor Abu-Odeh has challenged us in her past work to reconsider what precisely the term "Islamic" in the context of a legal system is supposed to signify. ${ }^{2}$ She has urged us to give greater consideration to the deep and abiding impact caused by the rupture of colonialism. ${ }^{3}$ She has specifically identified the rise of the legal transplant within the separate Muslim nation-states to which colonialism gave rise as being worthy of far more study than it has received, to the derogation of medieval scholarly opinion that in many cases is of trifling value to anyone interested in modern law in a Muslim state. ${ }^{4}$ Her contributions should not be gainsaid; anyone interested in the law as practiced in the modern Muslim world would be remiss not to know her work and know it well.

In this latest piece, Professor Abu-Odeh builds on her earlier work respecting Islamic law but adds a new target to her sites, that of the study of national security. ${ }^{5}$ That is, we already knew Professor Abu-Odeh's view of the typical Islamic law scholar. He is one who is focused either on the resurrection of the shari'a in some sort of reconstructed form or involved in a thoroughly misguided search for the truly "Islamic" in our contemporary, messy, hybrid and multipolar world, often disappointed when he cannot find it. ${ }^{6}$ In this work, Professor AbuOdeh informs us that the national security scholar is guilty of something of the same, by ignoring "Muslims as agents of modern history" in considering what national security is supposed to be about. ${ }^{7}$

Taking the two strands together, it becomes apparent that restoring this focus on Muslim agency preoccupies Professor Abu-Odeh in her work. For Professor Abu-Odeh, such a restored focus would not only reinvigorate the study of Islamic law, but it would also realign priorities within the world of national security by reducing its myopic America-centric vision, and, more centrally, by promoting a broader understanding of precisely what types of entities, or "nations," may legitimately lay claim to it. ${ }^{8}$ Her resulting prescriptions respecting the resurrection of a larger single Arab state from the colonial fragmentation that followed the

1. Kant was referring to the work of David Hume, which profoundly influenced his own philosophy. Immanuel Kant, Prolegomena to ANy Future MetaPhysics 6 (James Fieser trans., Forgotten Books 2008) (1783), available at http://www.forgottenbooks.org/info/9781605069876.

2. Lama Abu-Odeh, The Politics of (Mis)recognition: Islamic Law Pedagogy in American Academia, 52 AM. J. COMP. L. 789, 800-01 (2004).

3. Id. at 790 .

4. Id. at 790-91.

5. Lama Abu-Odeh, Islam in the Inter(National), 10 SANTA ClARA J. INT’L L. 205 (2012).

6. See Abu-Odeh, supra note 2, at 798-99 (discussing the work of Wael Hallaq).

7. Abu-Odeh, supra note 5 , at 208.

8. Id. at $209-210$. 
First World War are certainly stunning in their audacity. ${ }^{9}$ Furthermore, her claims provoked no shortage of debate, some of it quite heated, among the participants at the Religion and International Law Symposium at Santa Clara University School of Law. ${ }^{10}$

I can only applaud Professor Abu-Odeh's focus on the notion of Muslims as agents of their own history. Like her, I find much that is wrong with what passes for national security discussions in our times. In particular, a theory of national security that seems to view coolly, for example, the possibility of democratic rule in Syria as compared to the continued rule of a vicious dictator is surely problematic. ${ }^{11}$ The issue is not even that to which Professor AbuOdeh refers, ${ }^{12}$ of whose national security is being furthered by the distasteful outcome of continued Assad control. Rather, we may well wonder whether or not it is sensible to describe the continuation of the status quo in Syria, complete with a military preoccupied with suppressing legitimate nonviolent dissent and an internal terror-inducing security apparatus designed to preserve the rule of one despot indefinitely, ${ }^{13}$ as being related to the national (as opposed to personal) security of anyone. We live in a world, after all, in which those leading the most threatening plot ever on American soil were overwhelmingly citizens of Arab states whose regimes were among America's closest allies, including on matters that pertain to national security. ${ }^{14}$ One needs more, in the end, than a fearsome security, force in order to preserve "national security"; one needs a citizenry dedicated to the political and economic system, seeking its preservation and indeed its advancement. A supposedly "stable" regime, so pathetic in its ability to inspire confidence in its governance that a village fruit vendor who sets himself on fire may bring down the entire regime, simply does not fit the bill. ${ }^{15}$

These are but musings, to be clear. I claim no expertise in the area of national security law, much less national security policy. I only wish to join my voice to that of Professor AbuOdeh, suggesting that something appears amiss, and leave the balance to those more competent to engage in the debate. I shall turn, therefore, in the balance of this essay, to my own broader questions, which relate to the specific prescription she employs to deal with the obvious problems of national security she outlines above. These relate to the establishment of a single Arab state that is the home of all the Arab peoples. I wonder whether, in advocating

9. Id.

10. Question and Answer Session, Panel IV at the Santa Clara University School of Law Symposium: Religion and International Law (Feb. 19, 2011) [hereinafter Symposium].

11. David Schenker, A Fighting Chance: Why Obama's Support for Syria's Nonviolent Protest Isn't Enough, NEw REPUBLIC (Oct. 25, 2011), available at http://www.tnr.com/article/politics/96607/syriabashar-al-assad-obama-ambassador-robert-ford (describing limited U.S. support for Syrian protestors partly out of fear of instability and civil war in Syria).

12. Abu-Odeh, supra note 5 at 210.

13. Anthony Shadid, Rejecting Offer of Dialogue, Protestors Return to the Streets, N.Y. TIMES, June 25, 2011, at A8 (describing the use of overstretched military to suppress dissent).

14. PhILIP ZELIKOW ET AL., The 9/11 Commission Report: Final Report of the National Commission on Terrorist Attacks Upon the United States, in NAT'L COMM'N ON TERRORIST ATTACKS UPON THE U.S. 160 (2004) (describing leading role of Mohammad Atta, an Egyptian, in 9/11 attacks), 231 (describing twelve of thirteen 9/11 "muscle hijackers" as being from Saudi Arabia).

15. Kareem Fahim, Slap to a Man's Pride Set Off Tumult in Tunisia, N.Y. TIMES, Jan. 22, 2011, at A1, available at http://www.nytimes.com/2011/01/22/world/africa/22sidi.html?pagewanted=all (the reference is to Mohamed Bouazizi, whose self-immolation inspired the Tunisian revolt that led to President Ben Ali's ouster). 
such a solution, a contradiction in her work might well be unearthed. It is one thing, after all, to call for changes in regimes or in economic governance in states which seem to have broadly disaffected citizens. It is quite another to call for an obliteration of those states entirely and a return to promises of an ethnically defined nation ${ }^{16}$ made by the United Kingdom nearly a century ago. Might we accuse Professor Abu-Odeh, that is, of doing vis-a-vis the Arab what she has deftly and with much justification decried in the study of the Islamic? Is she searching for the genuinely Arab as a "pearl in the shell"? ${ }^{17}$ Is she taking account of Arabs as agents of their own history, a history which has developed to no small extent since the end of the First World War, when the dream of the Arab state was thwarted? ${ }^{18}$ Is the resurrection of a single Arab state therefore almost as anachronistic an exercise as attempting the resurrection of Islamic law "in this or that field"?19 These questions are worth exploring, and the balance of this Comment shall endeavor to address them.

In keeping with Professor Abu-Odeh's laudable project to write Arabs, and Muslims, as the case may be ${ }^{20}$ back into their own history, as agents of change in their respective nations, Part II discusses the role that post-colonial Arab political history might have played in blunting the force of a once near ubiquitous call for a grand Arab state. Part III deals with a more logically central objection respecting the linking of the concept of the "nation" to a single Arab state, and the seemingly sweeping rejection of any political entity other than this as being fundamentally illegitimate. Rather than rendering these Arabs as agents of their own history, with cognizance being given to the historical circumstances in which they find themselves, such an approach comes dangerously near disregarding much legal development, in particular concerning the legal transplant, that Professor Abu-Odeh has elsewhere compellingly maintained deserves greater consideration than it has received. ${ }^{21}$ More than this can be said, in fact. If the post-colonial nation-states count for nothing, then the distinction as between the Arab state and the Islamic caliphate is almost reduced to ideological preference rather than anything having to do with historical realities as they have

16. At the Symposium, Professor Abu-Odeh suggested that the Arabs were not an ethnic group but a linguistic one, defined as those whose first language was Arabic. Abu-Odeh, Symposium, supra note 10. I certainly understand the hesitation in describing a people as diverse as the residents of Khartoum to those of Damascus as being united on any sort of genealogical basis, but surely more is at work than mere language. My sister in law is a Baghdad-born Kurd whose first language is Arabic, but she does not regard herself as an Arab, nor would any Arab Iraqi regard her as such. The same might be said of an Arab Iraqi born abroad, or in a Kurdish region, such that their first language was not Arabic. The Arabs, it seems to me, are indeed an ethnicity, even if it is fundamentally the Arabic language, more than genealogical similarity, that unites them.

17. Abu-Odeh, supra note 5 at 209.

18. Abu-Odeh, supra note 2 at 810.

19. See Abu-Odeh, supra note 5 at 208.

20. Professor Abu-Odeh makes an awkward jump, one she recognizes as creating confusion, in beginning her paper by describing a dichotomy between Islamic law and national security, and the disregard given to Muslims in history, and then focusing on a solution that results in the creation of an ethnic (Arab) nation-state. This was a matter discussed at the Symposium at some length, and I am sure will be addressed by Professor Abu-Odeh as her ideas develop. For now, in order to comment on her paper coherently, I feel compelled to make the same awkward jump, albeit with some misgiving, given how stridently, and perhaps overzealously, I have criticized others in the past for conflating the Arab and the Muslim. See Haider Ala Hamoudi, Orientalism and the Fall and Rise of the Islamic State, 2 MIDDLE EASTERN L. \& GOVERNANCE 81, 96 (2010).

21. See Abu-Odeh, supra note 2 at 790. 
existed and as Arabs have inhabited them over the past century. Part IV offers a partial, hybrid model for understanding both the Arab, and the Islamic, in modern Arab states. Part $\mathrm{V}$ provides concluding thoughts.

\section{The Pan-Arab Disaster}

Even casual students of Middle Eastern history are aware that the notion of a grand Arab state is not a novel one. (For clarity's sake, Professor Abu-Odeh nowhere suggests that it is.) The idea is most firmly associated with Egypt's former president, Gamal Abdul Nasser, but in fact spans a much broader spectrum of ruling Arab regimes. ${ }^{22}$ Syria and Iraq, until the 2003 invasion, belonged to competing wings of the most extreme pan-Arabist party, the Ba'ath, Ba'ath being Arabic for resurrection, and resurrection referring to the one Arab nation. ${ }^{23}$ In fact, Syria and Egypt went so far as to create a single state in 1958, the United Arab Republic. ${ }^{24}$ Even Qaddafi was a fervent advocate of the Arab Nation when the idea was in its heyday, seeking to replace Nasser as its charismatic leader upon Nasser's death. ${ }^{25}$

Yet to describe such movements as having been a disaster for the region is to understate the matter considerably. There is of course the complete lack of political success at unity. The Egyptian and Syrian political merger into the United Arab Republic was messy and short lived. ${ }^{26}$ Qaddafi's fitful efforts proved even less promising; few seemed interested in conferring Nasser's mantle upon him. ${ }^{27}$ The two most fervent advocates of the single Arab state after Nasser, the regimes of Syria and Iraq, spent decades as bitter enemies. ${ }^{28}$ Perhaps the most fatal political setback to the cause of the Arab state was the disastrous 1967 war with Israel, won by the Israelis over Nasser and his Arab allies in just six days, during which Jerusalem was lost to Israel, and the West Bank, the Gaza strip and the Golan Heights placed under Israeli occupation. ${ }^{29}$

In addition to these embarrassments, and perhaps just as importantly if we are to understand the evolution of Arab views and respect Arabs as agents in their own history, there is the complete misery that pan-Arab regimes caused their own people. We have seen recently what the people of Egypt and Libya appear to think of their own regimes, both ruled by leaders who claim or have claimed to uphold Nasser's principles. ${ }^{30}$ However, I focus herein on Iraq, the nation with which I am most familiar, personally and professionally, where the

22. Albert Hourani, A History of the Arab Peoples 407 (The Belknap Press of Harvard Univ. Press 1991).

23. Id. at 404; M.E. YAPP, The NeAR EAST Since ThE FIRST WorLd WAR 241 (Longman Group UK Limited 1991).

24. HOURANI, supra note 22 at 368 .

25. Id. at 428 .

26. YAPP, supra note 23 at 218.

27. HOURANI, supra note 22 at 428.

28. $I d$.

29. Id. at 413

30. Id. at 428 (describing Qaddafi); William E. Schmidt, Seeking His Own Power Base, Mubarak Builds on Nasser's, N.Y. TIMES, Oct. 24, 1982, at 44 (describing Mubarak's attempts to claim Nasser's legacy). 
paragons of the pan-Arab dream, the Ba'ath, ruled for thirty-five years. ${ }^{31}$ At the end of this period, oil rich Iraq emerged as an impoverished nation ruled by a despot isolated from the rest of the world. ${ }^{32}$ The country had suffered multiple wars in pursuit of the pan-Arab cause, among them a decade long war with Iran that led to the deaths of hundreds of thousands of Iraqis, ${ }^{33}$ which Iraqi President Saddam Hussein specifically claimed had been "won" on behalf of the "Arab nation." 34 The claim of victory may have seemed odd because Iraq had agreed to abide by the very 1975 agreement that Saddam Hussein had torn up on national television a decade earlier to start the war. ${ }^{35}$ However, relative to the disaster of the First Gulf War and the resulting crippling United Nations sanctions and to the Second Gulf War and the removal of the Ba'ath from power, the Iran war was, in retrospect, one of Iraq's more successful wars. There are also, lest we forget, the Anfal operations in northern Iraq, where 150,000 Kurds were killed, 36 and the repression of the Shi'a following the First Gulf War, where 300,000 were killed by tanks painted upon them the slogan, "No Shi'i lives after this day." 37 Meanwhile, as no less an authority than Kanan Makiya has documented, coming from the Arab intelligentsia, much less the Arab regimes themselves, was stunning silence to the unimaginable cruelty. One would have to search far and wide to find even mild Arab condemnation of some of the greatest human rights atrocities that had occurred in the region's history. To the contrary, to the extent these events were discussed, it was always in the form of post-hoc justifications. ${ }^{38}$ And these, I cannot but help but think to myself while reading Professor Abu-Odeh's work, are the elite of the peoples to whom I am asked to tie my political fortunes?

To be entirely fair, and complete, Professor Abu-Odeh does not deny in the slightest these disasters. ${ }^{39}$ Instead, she suggests, seemingly wisely, that the ideological excesses of the Ba'ath were attributable to their lack of political achievement. 40 That is, Iraq was not really the single Arab state that had been promised, everyone with even rudimentary knowledge of geography could see that, and thus it had to compensate for what it was not - the Arab nation - by pretending ever more aggressive and preposterous adherence to the unrealized idea. This may well be, though I feel compelled to add that however preposterous the claim, it seems to have deluded many a non-Iraqi Arab.

But the broader and more fatal problem remains that once we concede that the excesses occurred, whether for this reason or for any other, then we must ask what any responsible and responsive Iraqi Shi'i Arab (or Iraqi Kurd), to whom we seek to confer agency in her own history, is likely to think of pan-Arabism. The answer, I am afraid, necessarily casts serious

31. Marion FArouk-Sluglett \& Peter Sluglett, IRAQ Since 1958: From Revolution TO DiCTATORSHIP 304-05 (Tauris \& Co. ed., 2003) (1987).

32. Id.

33. Id. at $270-71$.

34. Id. at 283 .

35. Id. at 271 .

36. Farouk-Sluglett \& Sluglett, supra note 31 at 270.

37. Id. at 289 .

38. Makiya's detailed documentation of this from numerous sources is devastating. See KANAN MAKIYA, CRUELTY AND SILENCE: WAR, TYRANNY, UPRISING AND THE ARAB WORLD 253-83 (1993).

39. Abu-Odeh Remarks, Symposium, supra note 10.

40. Id. 
questions on the ideological appeal of the notion of a single Arab state. Far too much has happened at the hands of Saddam Hussein, with the complicity of the Arab intelligentsia, to make political reunification remotely appealing. The Ba'ath mantra, "One Arab Nation-The Eternal Message," seems, from my own observations over Iraq over the past several years, consigned to history's garbage bin - like "power to the people", it is more often used in parody than as an expression of genuine sentiment. If there is a parliamentary movement in favor of political unification of Iraq to the broader Arab world, I have not seen it. In fact, I would go further. I have not seen a single Iraqi politician advance any notion of political unification with any Arab state, let alone all of them.

Nothing I have seen in Egypt convinces me that the situation is any different in that vitally important Arab state. The demonstrations that convulsed Tahrir Square involved, as I saw it on Al Jazeera, ubiquitous flying of the Egyptian flag, calls for the amendment of the Egyptian constitution, and references to a dissolving and subsequent reelection of an Egyptian parliament. It is true, as Professor Abu-Odeh notes, that there was broad Arab (and Muslim) solidarity with the demonstrators at Tahrir Square, a point to which I shall return later. It is further true that such solidarity was often expressed in the hyperbolic language most famously exhibited by the French daily Le Monde after the horrors of 9/11 vis-a-vis the United States ${ }^{41}$ — we are all Egyptians now. But if we were Egyptians then, we are Syrians now, and we were Bosnians during the Srebernica massacres. The point is not that one desires political union, only that one's sympathy for another's plight has elicited a particularly strong reaction for some combination of reasons.

\section{The Problem of the Existing Nation States}

While in some ways, the issues raised in the previous section are fundamental, I do not wish to dwell on them excessively. The reason (in addition, of course, to customary space limitations for commentary of this sort) is that I do not feel that there is much that I can supply to the debate respecting the Arab lack of desire for Arab nationalism and the attendant reasons for that. I claim no particular expertise in political science, and in any event, the question deserves empirical study more than it does prognostications from law professors based on their individualized perceptions. I have no doubt that Professor AbuOdeh will disagree with me on the extent of the appetite for Arab nationalism, and I am certain that we could dispute that at some length. In the end, I can only hope that in keeping with her broader project to write Arabs back into their own history as agents thereof, that she give some consideration to what at least some later generations of Arabs might think of panArabism because of the severe abuses to which various manifestations of the doctrine have been put by Arab leaders with, I stress it again, considerable complicity by all too much of the Arab intelligentsia.

More saliently, if Professor Abu-Odeh is correct that there is no such thing as national security without a "nation" (a fact which I do not dispute), and if she is correct that in the

41. Jean-Marie Colombani, Editorial, Nous Sommes Tous Américains [We are all Americans], LE MONDE, Sept. 13, 2001 (Fr.) available at http://www.worldpress.org/1101we_are_all_americans.htm. 
context of the Arabs that nation is necessarily a single Arab state (a fact I dispute with some vigor), then this renders much more than the notion of national security troublesome. Specifically, it seems that in such an event, the entire legal system of the separate Arab nation states is fatally delegitimized. It is hard to understand how any different conclusion could be reached. That which makes the Sanhuri Civil Code into law is nothing more than its individual enactment (in varying forms) in the several Arab states under whatever rule of recognition might apply in the respective cases. ${ }^{42}$ Can it truly be said that these states, being less than nations, cannot impose security but somehow can impose law? Would it not be odd to talk of a state legitimate enough to create and administer law in some sort of effective fashion but unable to create security?

When I challenged Professor Abu-Odeh on the point at the Santa Clara Symposium, she agreed that the transplant has indeed developed deep roots. ${ }^{43}$ However, she argued, the transplant grew within the context of an authoritarian system, and would not have been able to develop as well as it had in the absence of such authoritarianism. ${ }^{44}$ This may or may not be true, but in any event, it is entirely beside the point. Either the transplant has become rooted or it has not, and if it has, than ipso facto some level of legitimacy is conferred upon the state (and derivatively the regime) that enacted it as a sovereign, entitled and empowered to confer the status of law upon legislative proposals. I do not mean this to derogate from my earlier concerns expressed in Part I, respecting the inability of states with deeply unpopular regimes such as Egypt (until its recent revolution) and Syria (currently) to create sufficiently secure domestic conditions. This is because, generally speaking, the legitimacy of the transplant runs much deeper than the legitimacy of any regime that happens to be in power in any given Arab state. The roots of the transplant are deep, and the mere fact that at this historical moment any particular Arab regime is deeply and fundamentally lacking in legitimacy does not render all law created by the entire state over the past eight decades or more inherently lacking in authority. This notion of broad illegitimacy to state law would necessarily be the conclusion, however, if we assume each Arab state to be an illegitimate construct incapable of creating security under any terms unless joined to a broader Arab nation.

After all, it would hardly do for the Egyptian legal community to reject the very notion of a sovereign Egypt, to deny it the dignity of sovereignty, to refuse to consider the possibility of living in some form of peace and security within it qua artificial, fragmented, post-colonial political construct and then seek to try, as Egypt has done, remnants of the former regime on the basis of a criminal law that is nothing more than the formal enactment of that very construct. ${ }^{45}$ Under Professor Abu-Odeh's formulation, it seems as if the entire legal community and the entire legal system must be dismissed as a farce, illegitimate in the eyes

42. See generally Haider Ala Hamoudi, The Death of Islamic Law, 38 GA. J. InT'L \& CoMP. L. 293, 310 (2010) (respecting the broad adoption of Sanhuri's Civil Code as the basis for much Arab private law beyond the law of the family).

43. Abu-Odeh Remarks, Symposium, supra note 10.

44. Id.

45. Neil MacFarquhar \& Liam Stack, Ex-Security Chief Hauled to Court As Egyptians Storm His Compound, N.Y. Times, March 6, 2011, at A11. 
of the citizenry, because it emanated from a source that was not itself a proper sovereign nation.

The problem is not that such a result is conceptually impossible. The enactment of law and its dismissal by those expected to live under it as fundamentally illegitimate is not, to be sure, an unprecedented phenomenon. I imagine and understand the Taliban would regard the pronouncements that emanate from Afghanistan's legislature with deep and fundamental contempt, paying them no heed and not interested in their implementation, even when it suits their interest. They would be, I surmise, supremely nonplussed by a trial of President Karzai for corruption under Afghan law enacted pursuant to Afghan constitutional dictate given their insistence that the Qur'an is their constitution. ${ }^{46}$ Whatever that might mean, it certainly entails a rejection of the Afghan constitution as a positivist innovation in violation of the will of God. Tribal areas of Pakistan seem well beyond the reach of state law as well, ${ }^{47}$ and much the same is said of Yemen's remote regions. ${ }^{48}$ In each of these cases, someone, somewhere may well be enacting law that formally is expected to be applicable, but legal enactment by a political entity not respected as sovereign over the relevant territory is met with disdainful indifference in the best case, contemptuous opposition in the worst. ${ }^{49}$

Professor Abu-Odeh's position is thus not an empirical impossibility in the abstract. Nevertheless, the dismissal of the state as illegitimate does not seem to describe much of the Arab world: transplants have grown, ${ }^{50}$ legal and business communities make use of them, ${ }^{51}$ and complaints as to the law are directed less towards its existence than to its poor implementation. What people seem to want in Egypt, at least insofar as a popular will can be gleaned from the protests and their aftermath, is precisely the application of the criminal laws - to the elements of the former regime. ${ }^{52}$ They hardly seem to regard such processes in the manner that I have surmised the Taliban would as to application of anticorruption laws to Karzai. I would belabor the point, and fortify it with ample citations but I hardly need to, as Professor Abu-Odeh does not contest it. She wants to preserve the transplant, and the ability of the state to legitimately project it, while denying that same state the ability to maintain security. Given that national security involves at its most basic level the promulgation and execution of law, it is unclear to me as to how this can be.

46. The notion that the Taliban use liberally the slogan that the Qur'an is their constitution and regard Afghan law with contempt has been confirmed in a conversation I had with Dr. Wadir Safi, former dean of the Faculty of Law and Political Science, Kabul University, on December 18, 2010.

47. Dean Nelson \& Javed Siddiq, Pakistan to Democratise Lawless Tribal Areas, The Telegraph, Aug. 14, 2009, available at http://www.telegraph.co.uk/news/worldnews/asia/pakistan/6031186/Pakistanto-democratise-lawless-tribal-areas.html.

48. Robert F. Worth, Is Yemen the Next Afghanistan? N.Y. Times MAG., July 6, 2010, available at http://www.nytimes.com/2010/07/11/magazine/11Yemen-t.html?pagewanted=1\&_r=1\&ref=yemen.

49. Naturally, we must distinguish between a polity ignoring generally unpopular and poorly enforced legislation (for example, the prohibition of jaywalking in Manhattan) and one which regards the entire process of lawmaking by a putative sovereign as fundamentally illegitimate. It is the latter phenomenon on which I focus here.

50. Hamoudi, supra note 42 at 310-11.

51. Id. at 322-25.

52. MacFarquhar \& Stack, supra note 45 (describing broad interest in trials of former powerful officials). 
The second problem is that if we strip the transplant of its legitimacy, then we have stripped the Arabs of their historical agency. Everything they have done is safely ignored as truly colonial in conception and practice. The Arabs have been powerless to do a thing to advance their well-being, other than to deny legitimacy to all that has happened, from Egyptian Supreme Constitutional Court decisions to Iraqi Shura Council actions, and call for something better in an entirely different political construct. That hardly seems palatable. I do not mean by this to suggest that the Arabs freely chose their own political boundaries or decided in all cases upon their own source for transplants. Obviously they did not. I do mean that as history's agents within constraints earlier established, they made choices, created systems, and altered those systems, politically, legally and economically, and that those systems, and those institutions, despite their colonial legacy, have developed far stronger roots than is commonly acknowledged, as Professor Abu-Odeh has herself pointed out in the past. $^{53}$

A third, and perhaps even more serious, problem lurks, once the agency is stripped. Suddenly, Professor Abu-Odeh's Islamic law scholar, unconcerned with the realities of modernity and focused on finding the truly Islamic, either through scholarly reconstitution or in some far flung corner of the globe, ${ }^{54}$ does not seem so misguided. The Arab, after all, under this conception, does not view his own state as being in any way legitimate; it cannot grant him security; it cannot create law; it is merely the artifact of a greater power whose authority he will not recognize unless compelled to, precisely as one is compelled to react to a criminal with a gun. Law cannot be found in such a construction. Where might it then be found? No doubt the defender of this vision will argue that it lies in the enactment of law in a true Arab state, the unrealized dream, based on the normative and ideological visions of the Arab people.

Yet, since we are disregarding modernity and ignoring the transplant and pretending that law cannot come from such post-colonial innovations, the Islamic law scholar Professor AbuOdeh describes so devastatingly, in this and in earlier work, ${ }^{55}$ might be forgiven for determining that, in fact, the true basis of the law lies not in the Arab nation but in the realization of the shari'a, and in its reconstitution on bases that existed prior to the colonialist rupture. The compelling criticism she has offered as against the Islamic law scholar, that he ignores centuries of history and creates law and principles of order that nobody alive is remotely familiar with, ${ }^{56}$ loses considerable force once one is willing to ignore decades of Arab state practice and dismiss those states as imposed fragments of a true nation, thereby suggesting they are not only incapable of providing security but also (derivatively, necessarily) incapable of establishing meaningful legal order. For at this point we have already determined that nothing legal or by way of order and security that anyone knows anything about is legitimate. The only question is where to locate the true source of natural order, in the Islamic, (allegedly) among a remote tribe in Yemen, or in the Arab, (allegedly)

53. Abu-Odeh, supra note 2 at 790 .

54. Abu-Odeh, supra note 5 at 208.

55. Abu-Odeh, supra note 2 at 798-99 (describing work of Hallaq).

56. Id. at 810 . 
among protestors in Tahrir Square, both working beyond history's grasp, both yearning for something they have never seen and hardly know, something they need an academic to help reconstitute in order to make real.

For my own part, I will beg the indulgence of advocates for both and maintain the competing visions to be somewhat fantastical, divorced of hard historical realities and from the lives and experiences of Arabs who have played an important role in shaping those realities. I do not mean to suggest, to be clear, that Professor Abu-Odeh would recognize her position as one that indulges in fantastical recreation, only that it is one that if reduced to its essence must either do so, or must give greater credence and substance to the legitimacy and authority of the several Arab states as they exist.

\section{Grasping at a Model of Hybridity}

Yet, as with all of her contributions, Professor Abu-Odeh is certainly onto something important in her discussions of the Arabs. It has nothing to do with political union, I would maintain, but with a certain transnational hybridity of ideas that is no less true as concerns the Arabs than as concerns the Muslims. That is to say, our conventional wisdom tells us that in an earlier generation, pan-Arabism was the premier force that shaped identities in the Middle East, ${ }^{57}$ while a generation later, the premier force was some form of Islamism. ${ }^{58}$ Rendered simplistically, this seems to imply the presence of an entire generation of secular nationalist and deeply committed Arabs raising a second generation who never thought of themselves as Arabs at all but whose true commitment was to the shari'a and its establishment at the center of any political construct created. Yet the Arab nationalist satellite channel Al Jazeera rose to spectacular prominence in our generation, the era of the supposed Islamists, and could hardly be accused of being an Islamist project. ${ }^{59}$ Much of the private law (beyond the law of the family), moreover, was more Islamic a generation ago, within the secularist generation, than it is now. ${ }^{60}$ Something is amiss in the narrative.

My purpose is not to turn the conventional wisdom on its head and suggest that we are the secular Arabs, our parents the Islamists, but only to suggest that there is some level of hybridity in the matter of our legal and political identities, in a manner that certainly affects legal output in the several Arab states of which we are separate citizens. That is to say, our generation, and that of our parents, regards ourselves as Arabs and Muslims alike, even if at some times and in some places we might emphasize one attachment above the other. The same is no less true of our respective national identities, as citizens of the separate Arab states.

57. See, e.g., HoURANI, supra note 22 at 407 (describing dominance of Arab nationalism in the 1960's).

58. NOAH FELDMAN, AFTER JiHAD: AMERICA AND THE STRUGGLE FOR ISLAMIC DEMOCRACY 20 (Farrar, Straus and Giroux eds., 2003) ("Secular nationalism was tried in the Arab world . . . and the consensus is that it failed. . . Islam itself, however, has not been similarly discredited in the realm of politics.").

59. Al Jazeera (NPR Morning Edition, Apr. 17, 2003), available at http://www.npr.org/templates/story/story.php?storyId=1235071\&ps=rs (describing the popularity of $\mathrm{Al}$ Jazeera as well as the deep mistrust of it by the most conservative of the Arab states, Saudi Arabia).

60. Hamoudi, supra note 42 at 324-25. 
With identity so conceived, law may be no more than the enactment of the legislatures of the separate Arab states, and when so enacted, I have maintained, has deep and abiding legitimacy. It would be foolish, however, to ignore the influence of the Arab, and the Islamic, on both the creation and the interpretation of law in any Arab state, for its Arab and Muslim citizens consider themselves not only Iraqi, Jordanian, or Egyptian, as the case may be, but also Arabs and Muslims. These are identities which carry with them substantial ideological and cultural commitments that affect law's creation and interpretation. It is the work of the great Egyptian jurist Sanhuri, which every decent Iraqi judge has on his shelf, a multivolume compendium of the Egyptian Civil Code. ${ }^{61}$ Every Iraqi law professor I know could recite seminal Egyptian decisions almost from memory. This is not to say that Iraqis do not regard their own legal systems as unique - Iraqi juristic texts are full of examples of circumstances where their law departs from that of Egypt. ${ }^{62}$ It is to suggest that Iraqis pay attention to legal developments in Egypt and are fundamentally influenced by them.

When the shari'a is relevant, in areas such as family law, constitutional repugnancy, and Islamic finance, the same holds true for the Islamic. To take a simple example, it would be hard to believe that when declaring the taking of money interest on a loan to be impermissible in Pakistan by virtue of its being repugnant to the shari'a, that the court determining the matter was not aware of and influenced by a similar conclusion reached in Egypt fourteen years earlier. ${ }^{63}$ Certainly for reasons ranging from linguistic compatibility to geographical proximity to political affinity, Arab lawmakers and judges are likely to be more influenced by each other even as to the Islamic than they are likely to be influenced by nonArab Muslim courts. However, that hardly portends entire disassociation from the broader Muslim world on key matters of law. Influences abound in all sorts of directions.

I do not claim, in my short remarks here, to have outlined in any sort of comprehensive fashion a model of hybridity that might well be employed across the Muslim world. I intend, instead, nothing more than to outline a set of ideas that might well capture more fully the very important trends that Professor Abu-Odeh has identified, one that gives, precisely as she admirably seeks to do, primary voice to the Arabs as agents of their own laws and legal histories.

\section{Conclusion}

Professor Abu-Odeh has laid out in her latest work a bold and thoughtful criticism of what is wrong with national security law, connecting it to earlier powerful and influential criticisms she has made of the study of Islamic law generally. In many ways, I consider

61. See generally ABDUl RAZZAQ Al-SANHURI, Al WASIT (Beirut, 3d ed. 2000).

62. See, e.g., Mundhir FAdHIL, Al WaSit Fi SHARH QANUN Al MADANi 320-21 (2006) (comparing Egyptian and Iraqi law respecting recovery for moral damages).

63. Compare Shari'ah Appellate Bench, Pakistan Supreme Court, Opinion Concerning Riba (J. Usmani section) (Dec. 22, 1999) (declaring money interest a violation of sharia), with Rector of the Azhar University v. President of the Republic, Case no. 20 of Judicial Year No.1/1985/Supreme Constitutional Court, (Egypt), reprinted in W. M. Ballantyne, Supreme Constitutional Court (Egypt) - Shari'a and Riba, 1 ARAB L.Q. 100 (1985) (coming to the same conclusion but deeming the matter nonjusticiable for constitutional purposes). 
myself a fellow traveler with Professor Abu-Odeh in unearthing a new method of understanding legal order in the Arab world, one that pays closer attention to historical and factual realities, and, perhaps more fundamentally, one that grants to the Arabs primary voice in the determination of their own political and legal order. There may well have been a day when granting to the Arabs such agency would have required the creation of a single Arab state, for only that single state could, in a legitimate and authoritative fashion, create and administer effectively a legal regime, and, derivatively, offer national security to its people and to the globe. That day, however, has long passed.

Understanding Arabs as historical agents and conferring upon them the power to determine their own national security (and their own legal and political regimes) in our times requires taking cognizance of two key historical phenomena which have had profound effects on the legal and political identities and expectations of the Arab peoples. The first of these is the gross abuse to which the grand Arab cause for a single nation has been put, and the effect that this has had on the appetite of the separate Arab polities for political union. The second is the deep and lasting effect of the legal transplant in each of the individual Arab states, so embedded in Arab consciousness that the peoples of the Arab world want less to see their own nations obliterated than to see its ineffective and despotic leaders tried under the very laws that are the product of the state that Professor Abu-Odeh dismisses as a national fragment imposed by colonialism.

Professor Abu-Odeh is to be credited for bringing scholarly attention to the second of these phenomena in her earlier work, but I fear her prescriptions in this paper minimize the importance of her magnificent earlier achievements and in some ways contradict them. That said, she is certainly correct that the importance of Arabism on the legal evolution of the several Arab states has been underestimated in the rush to ground everything in shari'a and deserves more attention than it has received. I would only argue, however, that what this points to is an epiphenomenon of inelegant, impure and motley hybridity in which transnational commitments of the Arab and Islamic variety help to shape the evolution and development of law's creation and interpretation in the several Arab states. We should embrace it. The utopias have brought us nothing but misery and disaster, after all. Let the mutts inherit the earth. They could do us no worse. 